ANADOLU JOURNAL OF EDUCATIONAL SCIENCES INTERNATIONAL

DOI: 10.18039/ajesi.759910

\title{
Türk Filmlerinde Yer Alan Değerlerin İncelenmesi
}

\author{
Orhan ÜNAL ${ }^{1}$
}

\begin{abstract}
$\ddot{O} \mathbf{z}$
Toplumun geneli tarafindan doğru ve güzel olarak kabul edilen davranışlar olarak ifade edilen değer kavramının önemi ve bu alanda yapılan çalışmalar son yıllarda oldukça artmıştır. Günümüzde değerlerin aktarılması amacıyla çeşitli yöntem ve araçlar kullanılmaktadır. Bu araçlardan bir tanesi geniş kitlelere kolayca ulaşma imkanına sahip olan filmlerdir. Filmler yardımıyla bir ileti kolaylıkla izleyiciye aktarılabilir. Türk halkının Türk filmlerine olan ilgisi dikkate alındığında bu filmlerin içerik bakımından incelenmesi önem kazanmaktadır. Bu çalışma 2015-2018 yılları arasında vizyona giren Türk filmlerinde yer alan değerlerin belirlenebilmesi amacıyla hazırlanmıştır. Araştırma nitel araştırma yöntemine uygun olarak hazırlanmış, verilerin toplanmasında doküman analizi yöntemi kullanılmıştır. Araştırmanın veri kaynaklarını 2015-2018 yılları arasında yayınlanmış dört Türk filmi oluşturmaktadır. Örneklem seçiminde amaçlı örneklem yöntemlerinden olan ölçüt örneklem yöntemi kullanılmıştır. Araştırma verileri betimsel analiz yöntemiyle analiz edilmiştir. Araştırma kapsamında incelenen filmler araştırmacı tarafından oluşturulan içerik gözlem formu dikkate alınarak iki defa izlenmiş̧ir. Araştırma kapsamında incelenen dört filmin iki tanesinde (Dağ 2 ve Müslüm) olumlu değer ögelerinin olumsuz değer ögelerinden daha fazla olduğu, iki tanesinde de (Düğün Dernek 2: Sünnet ve Recep İvedik 5) olumsuz değer ögelerinin olumlu değer ögelerinden daha fazla olduğu sonucuna ulaşılmıştır. Filmlerde olumlu olarak en fazla yer alan değerlerin sevgi, sorumluluk ve dayanışma değerleri olduğu, olumsuz olarak en fazla yer alan değerlerin ise saygı, dürüstlük ve sorumluluk değerleri olduğu sonucuna ulaşılmıştır.
\end{abstract}

Anahtar kelimeler: eğitim, film, Türk filmi, değer.

Attf: Ünal, O. (2020). Türk filmlerinde yer alan değerlerin incelenmesi. Anadolu Journal of Educational Sciences International, 10(2), 910-929. DOI: 10.18039/ajesi.759910

\footnotetext{
${ }^{1}$ (Sorumlu Yazar) Arş. Gör., Ondokuz Mayıs Üniversitesi, Eğitim Fakültesi, Sosyal Bilgiler Eğitimi, Türkiye, orhan.unal@omu.edu.tr, https://orcid.org/0000-0002-4604-6210
} 
ANADOLU JOURNAL OF EDUCATIONAL SCIENCES INTERNATIONAL

DOI: $10.18039 /$ ajesi.759910

\title{
Analysis of Values in Turkish Movies
}

Orhan ÜNAL ${ }^{1}$

\begin{abstract}
The importance given to the concept of value, which is defined as the behaviors that are accepted as correct and beautiful by the society in general, and the studies in this field have increased considerably especially in recent years. Today, various methods and tools are used to transfer values. One of these tools is movies that can easily reach large audiences. With the help of movies, a message can easily be transferred to the viewer. Considering the interest of Turkish people in Turkish movies, it is important to examine these movies in terms of content. This study was conducted in order to determine the values in the Turkish movies that were released between 20152018. The research was carried out in accordance with the qualitative research method, and document analysis method was used to collect the data. The data sources of the research consist of four Turkish movies made between 2015-2018. Criterion sampling method, which is one of the purposeful sampling methods, was used in sample selection. Research data were analyzed with descriptive analysis method. The movies examined within the scope of the research were watched twice, taking into account the content observation form created by the researcher. It was found that positive value items were higher than negative value items in two (Dağ 2 and Müslüm) of the four movies examined within the scope of the study. In the other two movies (Dügün Dernek 2: Sünnet and Recep İvedik 5), it was concluded that the negative value items were higher than the positive value items. It was understood that the values of love, responsibility and solidarity were the most common positive values in the movies examined. On the other hand, it is concluded that the values of respect, honesty and responsibility are the most common negative values in the movies examined.
\end{abstract}

Keywords: education, movie, Turkish movies, value.

Cite: Ünal, O. (2020). Analysis of values in Turkish movies. Anadolu Journal of Educational Sciences International, 10(2), 910-929. DOI: 10.18039/ajesi.759910

\footnotetext{
${ }^{1}$ (Corresponding author) Res. Asst., Ondokuz May1s University, Faculty of Education, Department of Social Studies Education, Turkey, orhan.unal@omu.edu.tr, https://orcid.org/0000-0002-4604-6210
} 


\section{Giriş}

Değer; bir şeyin önemini belirleyen soyut ölçü, bir şeyin değdiği karş1lık, kıymet, yüksek ve yararlı niteliktir (Ulusoy ve Dilmaç, 2016). Türk Dil Kurumu tarafından yapılan tanıma göre ise değer; bir şeyin önemini belirlemeye yarayan soyut ölçü, bir şeyin değdiği karşılık, kıymettir (TDK, 2019). Değerler eğitimi ise kısaca değerlerin öğrencilere kazandırılması amacıyla yapılan çalışmaların tümü olarak tanımlanabilir. Özellikle son yıllarda toplumsal yaşamda meydana gelen hızlı değişim, teknolojik yeniliklerin günlük yaşam üzerindeki etkisi ve bireyselleşme sürecinin hız kazanması gibi gelişmeler sağliklı toplum yapısına ve birbirine saygılı insanların varlığına olan ihtiyacın önemini bir kez daha hatırlatmıştır. Öncelikle aile kurumu olmak üzere çevre ve okul bireyin değer kazanımı üzerinde belirleyici unsurlardır (Ulusoy, 2019). Kişinin değer yargıları ve karakteri ailede oluşmaya başlar çevre ve okulda devam eder. Dolayısıyla sağlıklı toplum yapısının temelleri bu üç unsurun değer yargıları ve karakter oluşumu üzerindeki işlevleriyle doğrudan ilişkilidir. Değerler aynı zamanda davranışlara rehberlik eden ilkeler ve inançlardır olduğu gibi bir fiilin iyi ya da kötü olarak değerlendirilmesine de kaynaklık ederler (Halstead ve Taylor, 2000). Dolayısıyla kişi yaptığı her işi değer inançlarına göre yapar. Değerlerine sahip çıkan bir insan düşüncelerinde iyiyi, güzeli ve doğruyu temel aldığı için eylemleri de bu doğrultuda olacaktır. Ancak değer yargılarından uzak bir kişilikten aynı düşünce ve hareket tarzını beklemek doğru olmayacaktır.

Sağlıklı toplum yapısının temini ve sürdürülebilir olması değerlerine bağlı bireylerin varlığı ile doğrudan bağlantılıdır (Kızılçelik ve Erjem, 1994). Bundan dolayı değerler ve değerlerin nasıl kazandırılması gerektiği ile alakalı çalışmalar özellikle son yıllarda oldukça artmıştır. Toplumun değerlerden uzaklaşması, geçmişte var olan bazı değerlerin unutulmaya yüz tutmuş olması ve bireyselleşme anlayışının getirdiği benmerkezci düşünce yapısı gibi sebepler bu türden çalışmaların artmasında ve önem kazanmasında etkili olmuştur.

Değerlerin aktarılmasında başlıca beş yaklaşım bulunmaktadır. Bu yaklaşımlar; telkin, değer açıklama, değer analizi, ahlak muhakeme ve model olama yaklaşımları olarak sıralanabilir. Bütün bu yaklaşımların yanında değerler eğitimi sürecinde kullanılabilecek ya da değerleri kazandırılması sürecinde etkili olan çeşitli materyaller bulunmaktadır. Bu çalışma da değerlerin aktarılması amacıyla kullanılabilecek araçlardan birisi olan filmlere odaklanmıştır. Filmler ortaya çıktığı toplumun bir parçası olduğu gibi o toplumu çeşitli yönlerden etkileme gücüne sahip araçlardır (Akıncı Yüksel, 2015). Filmlerin bu etki gücünde önemli olan iki unsur vardır: Birincisi filmlerin teknik özellikleri itibarıyla ses, görüntü ve hareket ögelerini bir arada sunması yani birden çok duyu organına bir anda hitap etmesidir. Bilindiği gibi öğrenme sürecinde ne kadar fazla duyu organı aktif olarak kullanılırsa öğrenmenin kalıcı olması da o ölçüde başarılı olacaktır (Öztürk, 1999; Keleş ve Çepni, 2005). İkincisi ise filmin olay ve olguları soyutluktan kurtararak somut bir şekilde sunması, gerçekçi bir anlatıma sahip olması ve gündelik konuları yansıtmasıdır. Diğer bir deyişle içinde bulunduğu toplumu ve toplumdan aldıklarını sanatsal bir şekilde yine topluma sunmasıdır (Birkök, 2008).

Filmler sayesinde bir ileti kolaylıkla geniş kitlelere ulaştırılabilir. Özellikle günümüzde filmlerin izleyiciyle buluştuğu sinema salonları, televizyon ekranları ve internet platformları gibi ortamlar göz önünde bulundurulursa filmlerin insanlara ulaşma gücü daha iyi anlaşılacaktır. Türkiye'de insanlar günlük ortalama 3 saat 34 dakika televizyon izlemektedir (RTÜK, 2018). Yine RTÜK tarafindan 2020 yılında kamuoyu ile paylaşılan veriler oldukça dikkat çekicidir. Araştırmaya göre ortaokul öğrencileri günlük ortalama 1 saat 26 dakika cep telefonu kullanmakta, 1 saat 29 dakika televizyon izlemekte, 2 saat 13 dakika internet kullanmakta ve 1 saat 30 dakika da ders çalışmaktadırlar. Araştırmada ulaşılan diğer bir sonuç ise ortaokul öğrencileri tarafindan en fazla izlenen program türünün $\% 51,5$ oranıyla dizi 
filmler ve \%41 oranıyla da filmler olmasıdır (RTÜK, 2020). Bununla birlikte sinema salonlarına giden seyirci sayısı da geçmişten günümüze artış göstermektedir. 2005 yaklaşık olarak 27 milyon 800 bin kişi, 2010 y1lında 41 milyon 500 bin kişi, 2015 yılında 60 milyon 200 bin kişi ve 2018 yılında ise 70 milyon 400 bin kişi sinema salonlarını ziyaret etmiştir (Box Office Türkiye, 2019). Ayrıca film karakterlerinin izleyiciler üzerinde etki bıraktığı, izleyicilerin filmlerin kahramanlarını kendilerine örnek aldığ 1 ve onları taklit ettiği de bilinmektedir (Kim, Agrusa, Lee ve Chon, 2007). Benzer bir çalışmada filmlerin eğitim ortamlarında kullanılmasının öğrencilerin karakter gelişimleri üzerinde olumlu etkiye sahip olduğu vurgulanmıştır (Russel III ve Waters, 2014). Roberts, Dean ve Nienhuis (2003) filmlerin eğitimin birçok alanında kullanılabilecek bir materyal olmasının yanında özellikle değerler gibi soyut kavramların somutlaştırılarak öğrencilere aktarılmasında da kullanılabileceğini vurgulamışlardır. Weinstein (2001) ise filmlerin öğretim materyali olarak kullanılmasının sıradanlığı ortadan kaldırma ve derse yönelik motivasyonu artırma gibi faydaları olduğunu ifade etmiştir.

Filmler değerler eğitimi sürecinde bilinçli olarak kullanıldığında olumlu sonuçlar verebildiği gibi günlük hayatımızın bir parçası olması nedeniyle içerdiği olumsuz iletilerden dolayı değerler üzerinde zararlı etkiler de bırakabilmektedir. Bu noktada değerlerin kazandırılması sürecinde kullanılacak filmlerin içeriği oldukça önem taşımaktadır. Nitekim filmlerin içerikleri, hitap ettikleri kitle vermek istedikleri mesajlar farklılık gösterebilmektedir.

Alanyazında değerler eğitimi hakkında yapılan çalışmaların genellikle yazılı eserlerin değerler eğitimi bağlamında incelenmesi üzerine odaklandığı görülmektedir. Önemli şair ve yazarların önemli eserleri değerler eğitimi bağlamında birçok çalışmaya konu olmuştur (Öncü, 2015; Şahin, 2017; Torun, 2019). Günümüzde oldukça önemli olan ve zamanla günlük hayatımızın bir parçası haline gelen filmlerin değerler eğitimi açısından incelenmesine yönelik çalışmalar genellikle çocuklara yönelik çizgi filmlerin incelenmesine dayanmaktadır. Sevim (2013) çalışmasında çocuklara yönelik çizgi filmleri karşılaştırmıştır. İzleme oranları dikkate alınarak seçilen üç yabancı üç yerli çizgi film içerdiği değerler bağlamında karşılaştırmıştır. Yorulmaz (2013a) Caillou çizgi filmini içerdiği din ve değerler eğitimi unsurları bakımından incelemiştir. Yine Yorulmaz (2013b) Pepee çizgi filmini benzer şekilde din ve değerler eğitimi bağlamında incelemiştir. Karakuş (2015) Niloya çizgi filmini içerdiği değerleri dikkate alarak incelemiştir. İnan (2016) TRT Çocuk kanalında 2016 yılında yayınlanan on bir farklı çizgi filmi evrensel ve yerel değerler bağlamında incelemiştir. Karaca (2019) TRT Çocuk kanalında yayınlanan Rafadan Tayfa çizgi filmini içerdiği değerler bağlamında incelemiştir. Demir (2019) çalışmasında iki yerli ve iki yabancı çizgi filmi incelemiş ve karşılaştırmaya tabi tutmuştur. Ünsal (2019) araştırmasında öğrenci velilerine uyguladığı anket sonucunda çocukların en fazla izlediği beş çizgi filmi belirlemiş ve bu çizgi filmleri içerdiği değerler bağlamında incelemiştir.

Çizgi filmlerin haricinde kalan film ve animasyon filmlerinin değerler bağlamında incelenmesine yönelik çalışmalar ise sınırlı sayıda kalmıştır. Oysa değerler eğitimi üzerine yapılan çalışmalar gerekli ön koşullar sağlandığı takdirde filmlerin de değerler eğitiminde bir araç olarak kullanılabileceğini göstermektedir (Eşitti, 2016). Beldağ ve Yarar Kaptan (2017) arabalar filmini içerdiği değerler açısından incelemişlerdir. Kavun (2018), 82 adet Kemal Sunal filmini içerdiği değerler bağlamında analiz etmiştir. Turhan (2018) Türk yapımı altı adet animasyon filmini içerdiği değerler bağlamında incelemiş̧ir. Aydemir (2019) Zeki Alasya-Metin Akpınar filmlerini değerler eğitimi bağlamında incelemiştir. Kanar (2019) Arabalar 1 animasyon filmi özelinde animasyon filmlerinin çocukların değer gelişimi üzerindeki etkisini incelemiştir.

Bu çalışma yakın dönemde vizyona giren (2015-2018 yılları arası) Türk filmlerinde yer alan değerlerin belirlenebilmesi amacıyla hazırlanmıştır. Araştırma kapsamında incelenen filmler vizyona 
girdiği yılda o yılın en çok izlenen filmleridir. İncelenen dört film sinema salonlarında yaklaşık olarak toplam 23 milyon 500 bin kişi tarafindan izlenmiştir. Ayrıca araştırma kapsamında incelenen filmlerin Türk yapımı filmlerden oluşmasında Türk halkının sinema salonlarında Türk filmlerini yabancı filmlere oranla daha fazla tercih etmesi ve milli değerlerin bu filmlerde daha fazla yer alması gibi nedenler etkili olmuştur. Alanyazında son yıllarda vizyona giren Türk filmlerinin değerler bağlamında incelenmesine yönelik çok az sayıda çalışma olmasından dolayı bu çalışma alanyazında bu konudaki boşluğu doldurması bakımından önem taşımaktadır.

\section{Yöntem}

\section{Araştırma Modeli}

2015-2018 yılları arasında vizyona giren dört adet Türk filminde yer alan değerleri incelemeyi amaçlayan bu çalışma nitel araştırma yöntemine uygun olarak hazırlanmıştır. Nitel araştırmalar gözlem, görüşme ve doküman analizi gibi nitel veri toplama yöntemlerinin kullanıldlğgl, alglların ve olayların doğal ortamda gerçekçi ve bütüncül bir biçimde ortaya konmasına yönelik nitel bir sürecin izlendiği araştırma olarak tanımlanabilir (Yıldırım ve Şimşek, 2011).

\section{Veri Kaynakları}

Araştırmanın veri kaynaklarını 2015-2018 yılları arasında yayınlanmış dört adet Türk filmi oluşturmaktadır. Filmlere ilişkin veriler Tablo 1'de sunulmuştur. Filmlerin seçiminde izlenme oranları dikkate alınmış ve her yılın en çok izlenen filmi incelemeye tabi tutulmuştur. Veri kaynaklarının seçiminde amaçlı örneklem yöntemlerinden ölçüt örneklem yöntemi kullanılmıştır. Ölçüt örneklemede amaç araştırmacı tarafından belirlenen ölçütlere uygun durumların araştırmaya dâhil edilmesidir (Yıldırım ve Şimşek, 2011). Ölçüt olarak filmlerin 2015-2018 yılları arasında vizyona girmesi ve belirtilen aralıktaki dört yılda her yılın en çok izlenen filmi olması ölçütleri dikkate alınmıştır.

Tablo 1: Araştırma Kapsamında Incelenen Filmlerin Künyesi

\begin{tabular}{llllc}
\hline Filmin Adı & Yönetmen & Başrol Oyuncuları & $\begin{array}{l}\text { Vizyon } \\
\text { Tarihi }\end{array}$ & Süre \\
\hline Düğün Dernek 2- Sünnet & Selçuk Aydemir & Ahmet Kural- Murat Cemcir & 2015 & $115 \mathrm{dk}$. \\
\hline Dağ 2 & Alper Çağlar & $\begin{array}{l}\text { Çağlar Ertuğrul- Ufuk Bayraktar- Ahu } \\
\text { Türkpençe- Murat Sezerli }\end{array}$ & 2016 & $135 \mathrm{dk}$. \\
\hline Recep İvedik 5 & Togan Gökbakar & Şahan Gökbakar & 2017 & $113 \mathrm{dk}$. \\
\hline Müslüm & Ketche & Timuçin Esen- Zerrin Tekindor & 2018 & $136 \mathrm{dk}$. \\
\hline
\end{tabular}

İncelenen bu filmlerin konuları şu şekilde özetlenebilir: Dügün Dernek 2- Sünnet: Film komedi türünde bir devam filmi niteliğindedir. İlk filmde İsmail ve arkadaşları İsmail'in oğlu olan Tarık'ın düğününü yapabilmek için giriştikleri maceralar anlatılmaktadır. Bu filmde ise İsmail ve arkadaşları bu defa Tarık'ın oğlunu, yani İsmail'in torununu, sünnet ettirebilmek için yeni bir maceraya atılırlar. Başta küçük bir sünnet düğünü yapmak için yola çıkan ekip, başlarına gelen talihsizliklerin ve 
beceriksizliklerinin sonucunda kendilerini şehir genelinde bir sünnet düğünü hazırlığı yaparken bulurlar. Dağ 2: İlk filmde teröristlerin elinden kurtulmayı başaran Oğuz ve Bekir, yıllar sonra özel bir görev için Özel Kuvvetler 8. Muharebe Arama Kurtarma Timi'ne (MAK) katılır. Timin özel görevi ise Kuzey Irak'ta bir terör örgütü tarafından kaçırılan gazeteci Ceyda Balaban'ı kurtarmaktır. Ancak bu sefer düşman geçmişteki gibi bir tane değildir. MAK'ın karşısında bu acımasız coğrafyada birbiriyle çatışan birden fazla kuvvet vardır ve işler bu sefer hiç olmadığı kadar zordur. Recep İvedik 5: Film komedi türündedir. Recep İvedik'in mahalleden tanıdığı şoför İsmet ölür. İvedik, taziyeye gittiğinde İsmet'in son görevini üstlenmeye karar verir. Millî sporculardan oluşan ekibi Üsküp'e götürür. Ancak müsabakalar öncesinde sporcular rahatsızlanınca ülkesi adına yarışmak durumunda kalır... Müslüm: Dram ve biyografi türünde hazırlanan film temel olarak Müslüm Gürses'in çocukluktan ölümüne kadar olan hayatını anlatmaktadır.

\section{Verilerin Toplanması}

Araştırma kapsamında verilerin toplanması amacıyla doküman analizi kullanılmıştır. Doküman analizi; araştırılmak istenen olgu veya olaylarla ilgili bilgi içeren materyallerin analiz edilmesi olarak tanımlanabilir. Burada kast edilen materyaller yazılı materyaller olabileceği gibi film ve video gibi görsel materyallerden de oluşabilir. Hatta film ve video gibi görsel materyallerin araştırmacılara sunduğu bazı avantajlar da vardır. Yüz ifadeleri ve vücut hareketleri gibi sözel olmayan davranışların değerlendirilebilmesi, verilerin araştırmacı veya bir başka araştırmacı tarafından tekraren incelenebilmesine olanak sağlaması bu avantajlardan birkaçıdır (Yıldırım ve Şimşek, 2011).

Filmlerde yer alan değerlerin belirlenebilmesi amacıyla araştırmacı tarafından içerik değerlendirme formu oluşturulmuştur. Değerlendirme formu oluşturulurken MEB Sosyal Bilgiler Öğretim Programında (MEB, 2018) yer alan değerler (Tablo 2.) dikkate alınmıştır.

Tablo 2: Sosyal Bilgiler Dersi Programında Yer Alan Değerler

\begin{tabular}{lll}
\hline 1- Adalet & 7- Dayanışma & 13- Saygı \\
\hline 2- Aile birliğine önem verme (ABÖV) & 8- Duyarlılık & 14- Sevgi \\
\hline 3- Bağımsızlık & 9- Dürüstlük & 15- Sorumluluk \\
\hline 4- Barış & 10- Estetik & 16- Tasarruf \\
\hline 5- Bilimsellik & 11- Eşitlik & 17- Vatanseverlik \\
\hline 6- Çalışkanlık & 12- Özgürlük & 18- Yardımseverlik \\
\hline
\end{tabular}

Değerlendirme formlarının oluşturulmasından sonra örneklem grubunda yer alan filmler araştırmacı tarafından iki defa izlenmiştir. İlk izlemeler filmlerde yer alan olumlu değer ögelerinin belirlenebilmesi, ikinci izlemeler ise filmlerde yer alan olumsuz değer ögelerinin belirlenebilmesi amacıyla yapılmıştır. İzlenen filmlerde yer alan değerlerin tespiti amacıyla içerik gözlem formu kullanılmıştır. İçerik gözlem formu temel olarak; filmde yer alan değerlerin, bu değerlerin olumlu ya da olumsuz olma durumunun ve değerlerin filmin hangi dakikasında yer aldığının not edildiği bölümlerden oluşmaktadır. Her iki izlemede de filmlerde yer alan değerlerin kaç sahnede geçtiği ve bu sahnelerin ne zaman olduğu içerik gözlem formuna işlenmiş aynı zamanda değer ögelerinin içerik gözlem formunda yer alan değerlerle eşleştirmesi yapılmıştır. Bu noktada sadece doğrudan konuşmalar ve ikili diyalog 
cümleleri dikkate alınmamış duygu ifadeleri, jest ve beden hareketleri gibi sözel olmayan unsurlar da göz önünde bulundurulmuştur. Analiz sürecinde birden fazla değer ile eşleştirilebilecek ifade ve davranışlar da olmuş ve eşleştirmeler de bu doğrultuda yapılmıştır.

\section{Verilerin Analizi}

Araştırma verilerinin analiz edilmesinde betimsel analiz kullanılmıştır. Betimsel analizde amaç ilgili formdan elde edilen verileri düzenlenmiş ve yorumlanmış halde okuyucuya kişilere sunabilmektir. Elde edilen veriler belirlenen temalara göre sınıflandırılır, özetlenir ve yorumlanır. Bulgular arasında neden-sonuç ilişkisi kurulur ve gerektiğinde olgular birbirleriyle karşılaştırılır. (Bogdan ve Biklen, 1992; Yıldırım ve Şimşek, 2011). Bu bakımdan betimsel analizin içerik analizine kıyasla daha yüzeysel olduğu söylenebilir. Araştırma kapsamında incelenen filmlerde yer alan özellikle olumlu bazı değer ifadeleri filmlerde geçtiği haliyle doğrudan aktarılmış, olumsuz ifadeler ise durum tasviri şeklinde sunulmuştur.

Geçerliliğin sağlanabilmesi amacıyla araştırma süreci ve yöntemi detaylı olarak betimlenmiştir. Veri kaynaklarına ve niçin bu kaynakların seçildiğine ilişkin bilgiler aktarılmıştır. Ayrıca verilerin desteklenmesi amacıyla ilgili kaynaklardan sıkça doğrudan alıntılar yapılmıştır. Araştırma verileri iki alan uzmanının görüşüne sunulmuş, onlardan gelen öneriler doğrultusunda değişiklikler yapılmıştır. Yine geçerliliğin sağlanabilmesi amacıyla araştırma amacının ve sonuçlarının uyumlu olmasına gayret gösterilmiştir. Güvenirliğin sağlanabilmesi amacıyla belirlenen temalara ilişkin doğrudan alıntılar, hangi alıntının hangi temaya ait olduğunu belirtecek şekilde sunulmuştur. Ayrıca hangi ifadenin hangi tema ile eşleştirilmesi gerektiği konusunda da bir bilim uzmanı ile karşılıklı değerlendirme yapılmıştır. Değerlendirme sonucunda iki araştırmacı arasında yüksek düzeyde $(p>0,8)$ bir uyumun ortaya çıkması eşleştirmelerin güvenirliğini ortaya koymaktadır. Çalışmanın son hali iki bilim uzmanına sunulmuş ve yorumların başka araştırmacılara sorulması yöntemine başvurularak geçerlilik ve güvenirlik sağlanmaya çalışılmıştır. 


\section{Bulgular}

$\mathrm{Bu}$ başlık altında örneklem grubunda yer alan Türk filmleri ilk aşamada içerdikleri değerler bağlamında teker teker incelenmiştir. İkinci aşamada ise filmlerin genel değerlendirmesine ilişkin veriler sunulmuştur.

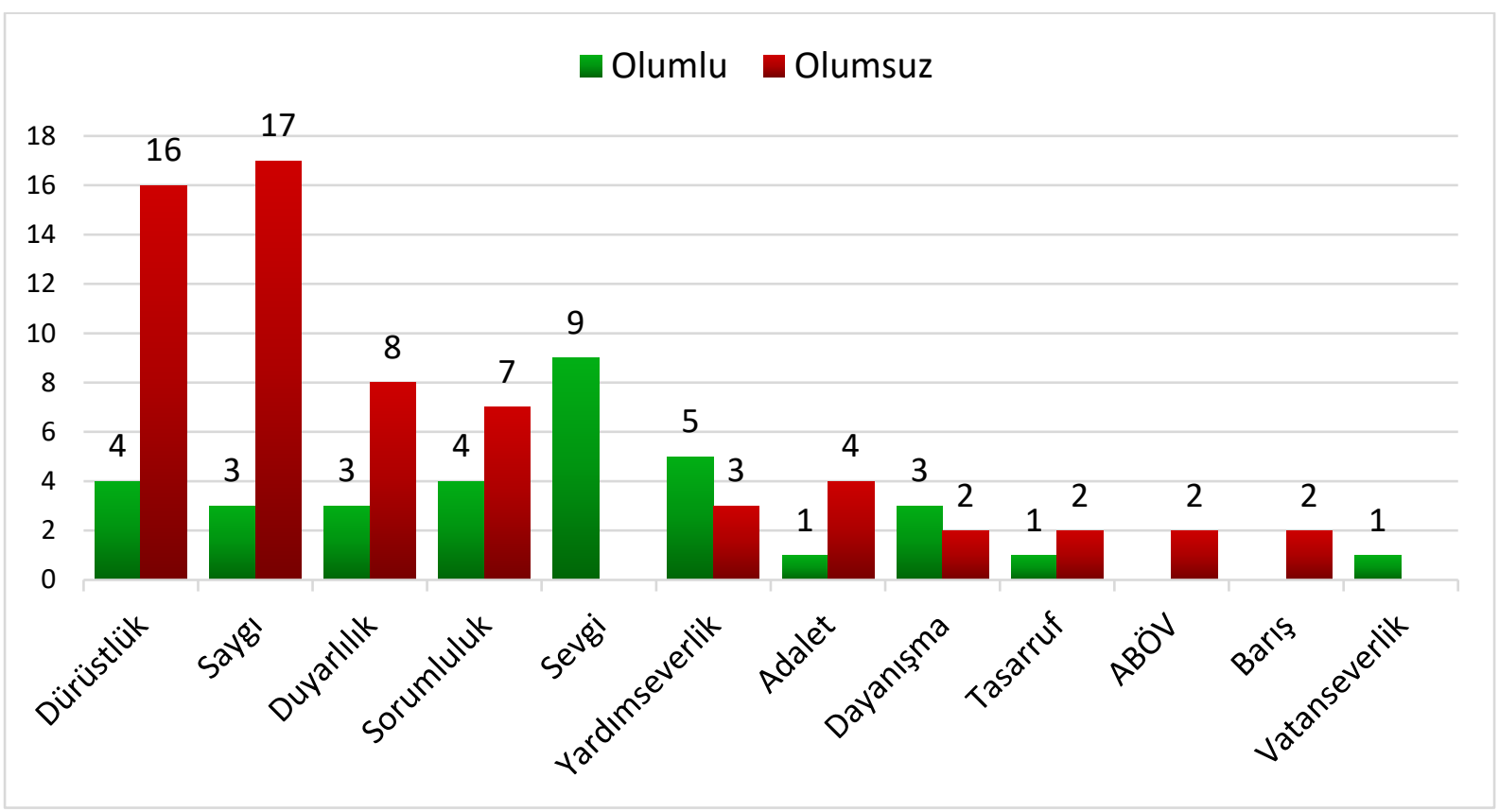

Şekil 1: Dü̈̆̈̈n Dernek 2: Sünnet (2015) Filminde Yer Alan Değerlere İlişkin Sütun Grafiği

Şekil 1 incelendiğinde Düğün Dernek 2: Sünnet filminde doğrudan veya dolaylı şekilde on iki değerin (34'ü olumlu, 63'ü olumsuz ögeler olmak üzere toplamda 97 öge) varlığından söz edilebilir. Bu değerlerin isimleri ve film içerisinde geçme sayıları ise şu şekilde ifade edilebilir: Dürüstlük (4 olumlu; 16 olumsuz), sayg1 ( 3 olumlu; 17 olumsuz), duyarlılık ( 3 olumlu; 8 olumsuz), sorumluluk (4 olumlu; 7 olumsuz), sevgi ( 9 olumlu), yardımseverlik ( 5 olumlu; 3 olumsuz), adalet ( 1 olumlu; 4 olumsuz), dayanışma ( 3 olumlu; 2 olumsuz), tasarruf ( 1 olumlu; 2 olumsuz); ABÖV ( 2 olumsuz), barış ( 2 olumsuz) ve vatanseverlik ( 1 olumlu).

$\checkmark$-Sana gelen bana gelsin İsmail. Bir şey diyeceğim İsmail. Ben seni çok seviyorum ha (Sevgi).

$\checkmark$-O nasıl iyi günler demek be Leyla! İlkokuldaymışım da vali çılkıp okullar kar tatilinde demiş gibi içim kıpır kıpır ya (Sevgi).

$\checkmark$-Hadi dürüst olalım. Siz işe mi gitmek istemiyorsunuz, rapor mu lazım size?

-Madem siz de dürüstlüğe benim kadar önem veriyorsunuz anlatayım (Dürüstlük).

$\checkmark$-Hayrına toplu sünnet töreni ha! Valla beni çok utandırdınız. Ne kadar düşüncelisiniz.

-Estağfurullah başkanım. Memleketimize bir hayrımız dokunsun istedik. Belki bir airport yapamadık, bir tren rayı döşeyemedik ama bizim de böyle bir hayrımı dokunsun (Yardımseverlik). 
$\checkmark$-Saçma sapan konuşmayın beyefendi. Doktorum ben. Bir insana ben nasıl öleceksin diye yanlış teşhis koyarım! (Sorumluluk).

$\checkmark$-İsler hiç umduğum gibi gitmedi. Bitti para.

-Ya niye hesaplı harcamıyorsun, niye çarçur ediyorsun müsrif herif! (Tasarruf).

$\checkmark$-Abi siz niye devlet malına zarar veriyorsunuz ya (Duyarlllik ve vatanseverlik).

X İsmail'in herhangi bir hastalığı olmamasına rağmen torununu sünnet ettirebilmek için karısına ve oğluna yirmi günlük ömrünün kaldığını söylemesi (Dürüstlük).

X Fikret'in otel personeline Leyla ile görüşmek istediğini söylemesi üzerine Leyla'yı arayan personelin Fikret'i tarif ederken "kel, göbekli, yaşlı bir dayı geldi seni soruyor" demesi (Saygi).

X Fotoğraf çekmek için binanın çatısına çıkan Fikret'in intihar etmek için oraya çıktığını düşünen bazı kişilerin "atlayacaksan atla boşuna bekletme bizi" ve "delikanllysan atla" gibi ifadeler kullanarak onu atlamaya yönlendirmesi (Duyarlılık).

X Yılmaz, Fikret ve Çetin'in petrolde arabalarının çalınması üzerine Yılmaz'ın 'Bize ne yaptılarsa aynısını yapacağız. Araba çalıp tüp kamyonunun peşine düşeceğiz. En sevdiğim" demesi (Adalet).

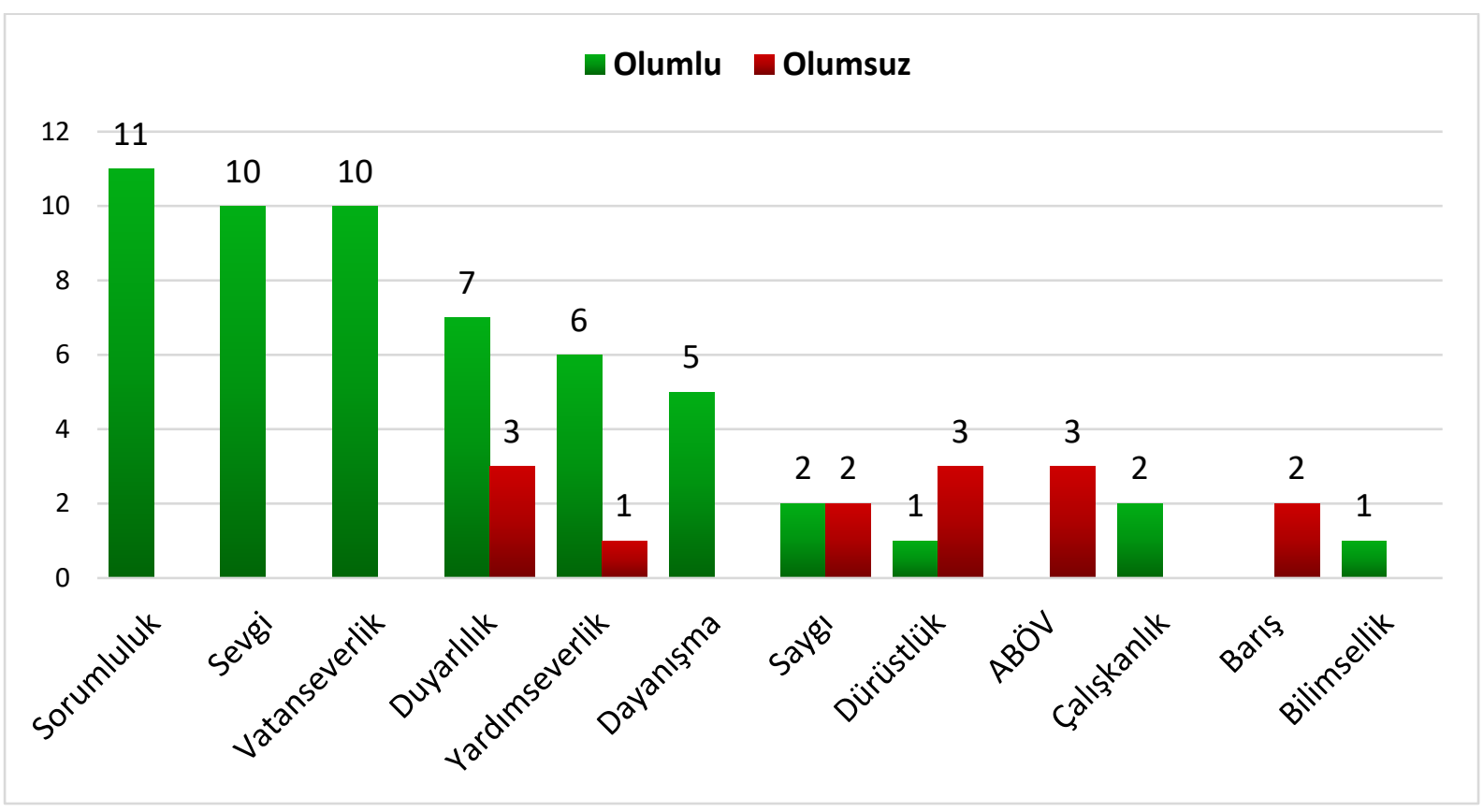

Şekil 2: Dă̆ 2 (2016) Filminde Yer Alan Değerlere İlişkin Sütun Grafiği

Şekil 2 incelendiğinde Dağ 2 filminde doğrudan veya dolaylı şekilde on iki değerin (55'i olumlu, 14'ü olumsuz ögeler olmak üzere toplamda 69 öge) varllğından söz edilebilir. Bu değerlerin isimleri ve film içerisinde geçme sayıları ise şu şekilde ifade edilebilir: Sorumluluk (11 olumlu), Sevgi (10 olumlu), vatanseverlik (10 olumlu), duyarlıl1k (7 olumlu; 3 olumsuz), yardımseverlik (6 olumlu; 1 olumsuz), dayanışma (5 olumlu), saygı ( 2 olumlu; 2 olumsuz), dürüstlük (1 olumlu; 3 olumsuz), ABÖV (3 olumsuz), çalışkanlık ( 2 olumlu), barış (2 olumsuz) ve bilimsellik (1 olumlu). 
$\checkmark$-Benim bir kızım vardı Ceyda, yaşasaydı senin gibi olsun isterdim. Yürekli, bilgili, boyun eğmeyen. Bu ülkeyi eleştirsin isterdim. Askeri de devleti de insanları da. Hataların yüzlerine vursun isterdim. Yeter ki sevsin. Ülkeyi ve içindekileri kusurlariyla sevsin. Sen de bizleri onurlandırmak için sev yeter Ceyda (Vatanseverlik).

$\checkmark$-Ben klasik adamım. Sebahat. Illk ve tek aşkım. Akçaabat'ın en güzel kızıydı Sebahat. Operasyondan bir gün önce evlendik. Bekleyemedik ona bir şey olur diye (Sevgi).

$\checkmark$-Komutanım neden birbirimizin paraşütlerini katlyyoruz?

-Unutmayın diye. Kimse sadece kendinden sorumlu değil. Herkes her zaman birbirine emanet (Sorumluluk ve dayanışma).

$\checkmark$-Senin dünyanda sorumluluk hissi idealist dünya görüşün. Tozpembe insanlara yardım etme hayali. Benimkinde ise çok iyi tanıdığım ailem gibi sevdiğim bu adamları, bu cesur adamları, hayatta tutmak. Tüm mesele görev (Sorumluluk ve sevgi).

$\checkmark$-Önemli olan iki şey var arkadaşlar: Vatan ve yanınızdaki adam. Bu iki şey için ölür ve öldürürsünüz. Arkadaşınız icabında bacağını tekrar sakatlayacak ama dostunu asla yarı yolda bırakmayacak (Vatanseverlik ve dayanışma).

X Askerlerden Oğuz’un sevdiği kızı onun yakın arkadaşlarından birisiyle aldattığını anlatması (ABÖV).

X Kendilerini almaya gelen helikoptere binmeyen ekibin komutanı Veysel telsizden niçin helikoptere binmediklerini soran komutanına, hava firtınalı olmamasına rağmen, havanın firtınalı olduğundan dolayı binemediklerini söylemesi ve tüm ekibin bunu onaylaması (Dürüstlük).

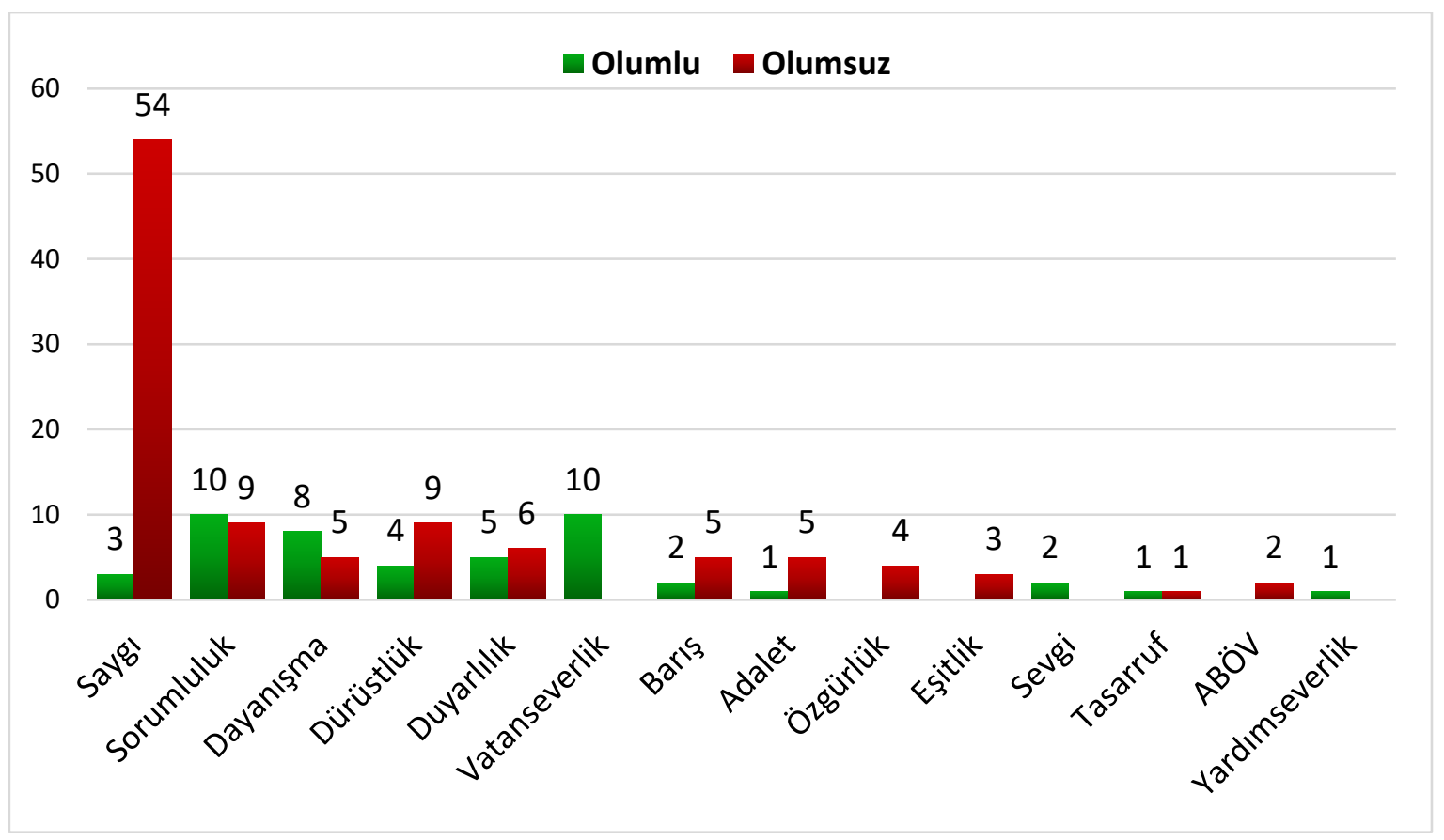

Şekil 3: Recep İvedik 5 (2017) Filminde Yer Alan Değerlere İlişkin Sütun Grafiği 
Şekil 3 incelendiğinde Recep İvedik 5 filminde doğrudan veya dolaylı şekilde on beş değerin (47'si olumlu, 103'i olumsuz ögeler olmak üzere toplamda 150 yerde) varlığından söz edilebilir. Bu değerlerin isimleri ve film içerisinde geçme sayıları ise şu şekilde ifade edilebilir: Saygı (3 olumlu; 54 olumsuz), sorumluluk (10 olumlu; 9 olumsuz), dayanışma ( 8 olumlu; 5 olumsuz), dürüstlük (4 olumlu; 9 olumsuz), duyarlılık ( 5 olumlu; 6 olumsuz), vatanseverlik ( 10 olumlu), barış ( 2 olumlu; 5 olumsuz), adalet ( 1 olumlu; 5 olumsuz), özgürlük ( 4 olumsuz), eşitlik ( 3 olumsuz), sevgi ( 2 olumlu), tasarruf (1 olumlu; 1 olumsuz), ABÖV ( 2 olumsuz) ve yardımseverlik ( 1 olumlu).

$\checkmark$-Akif, hemen çocuklarl topla doğru otobüse. He bu arada İstanbul'a döndüğümüzde bu sorumsuzluğunun hesabını sana soracă̆ım (Sorumluluk).

$\checkmark$ - Benim tanıdı̆̆ım Kara Ambar Kamyoncular Cemiyeti var. Orada dedim vatanını milletini seven, mert, delikanl, bayrak aşı̆̆ yiğit gençler var. Onları çağırırız ülkeyi temsil ederiz çekme mekme yok dedim. Bilmiyorum yanlış mı demişim!

-Söz konusu vatansa gerisi teferruattır. Ecdadımızın 600 yıl hüküm sürdüğ̈̈ bu topraklarda seni yalnız bırakmayız Recep Abi (Vatanseverlik).

$\checkmark$-Abi, amma söylendin ya! Tamam, gelme gelme ben hallederim.

-Ben geleceğim dediysem gelirim koçum. Arkadaşımı satmam ben (Dayanışma).

$\checkmark$-Bu gençlerin, bu çocukların hayalleri vardl, umutları vardl. Bütün hayallerini bitirdiniz çocukların (Duyarlılık).

$\checkmark$-Şunu söylemek istiyorum; Türk milleti olarak biz israfi hiç sevmeyiz. Hiç hoşumuza gitmez (Tasarruf).

$\checkmark$-Hep Türkiye'nin hakkın yiyorsunuz ama ya! Bu kadar Türkiye'nin hakkı yenmez hocam üst üste ya! (Adalet).

X Hakemlerin verdiği puanları beğenmeyen Recep'in elindeki spor aletlerini hakemlerin üzerine doğru atması (Sayg1).

X Otobüs seyir halindeyken şoför olan Recep'in muavini Nurullah'1 şoför koltuğuna geçirmesi ve bir süre sonra Nurullah'ın araç kullanırken uyuya kalması (Sorumluluk).

X Uzun atlama yarışında rakibinden iki santim daha kısa bir mesafeye atlayan Recep'in ölçüm yapan hakeme "Hocam iki santim için yakma beni. Dört santim ekle şuna. İkimiz görüyoruz başka gören yok." demesi (Dürüstlük ve adalet).

X Alkol aldıkları için arkadaşlarını azarlayan ve onları odalarına gönderen kafile başkanı Recep'in arkadaşları gittikten sonra yardımcısının kendisini "abi adamları şimdi kovdun ama kendin içiyorsun" demesine rağmen "bir şey olmaz" diyerek kendisinin de alkol almaya başlaması (Eşitlik ve dürüstlük). 


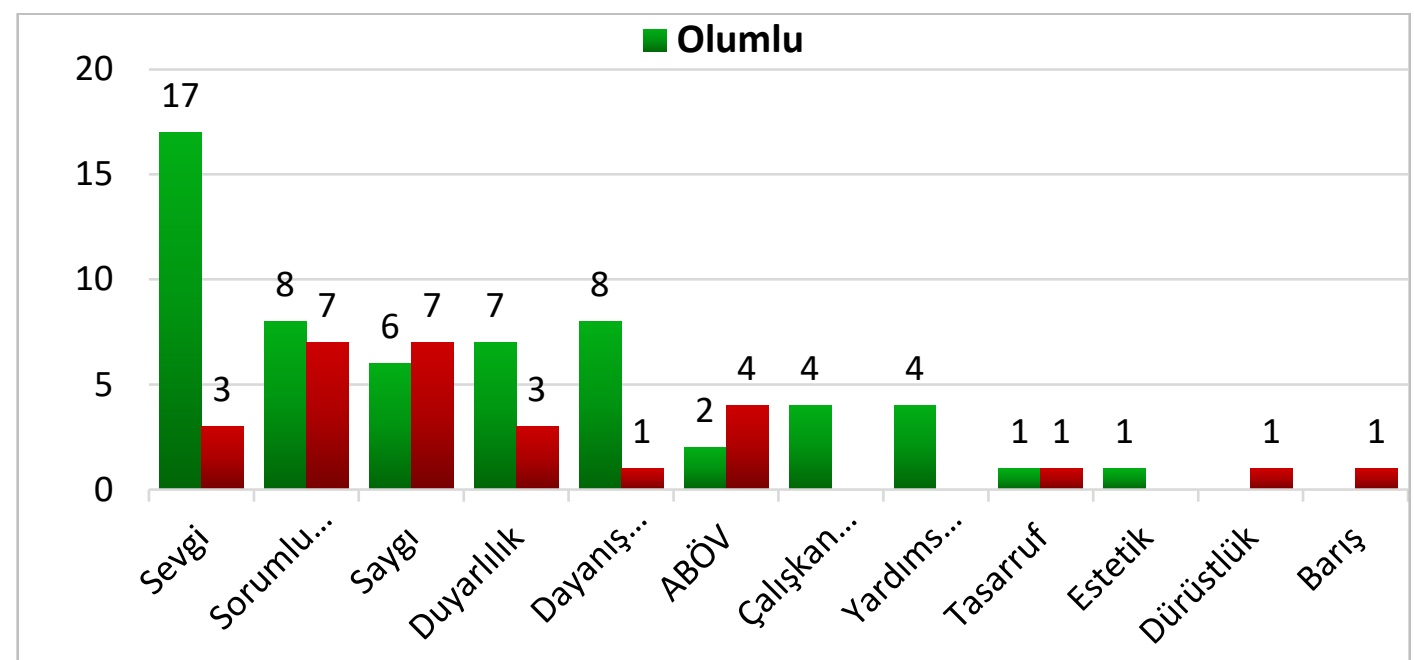

Şekil 4: Müslüm (2018) Filminde Yer Alan Değerlere İlişkin Sütun Grafiği

Şekil 4 incelendiğinde Müslüm filminde doğrudan veya dolaylı şekilde on iki değerin (58'i olumlu, 28'i olumsuz ögeler olmak üzere toplamda 86 yerde) varlığından söz edilebilir. Bu değerlerin isimleri ve film içerisinde geçme sayıları ise şu şekildedir: Sevgi (17 olumlu; 3 olumsuz), sorumluluk ( 8 olumlu; 7 olumsuz), saygı ( 6 olumlu; 7 olumsuz), duyarlılık ( 7 olumlu; 3 olumsuz), dayanışma ( 8 olumlu; 1 olumsuz), ABÖV (2 olumlu; 4 olumsuz), çalışkanlık (4 olumlu), yardımseverlik (4 olumlu), tasarruf ( 1 olumlu), estetik ( 1 olumlu), dürüstlük (1 olumsuz) ve barış (1 olumsuz).

$\checkmark$ - Benim tanıdı̆̆ım Kara Ambar Kamyoncular Cemiyeti var. Orada dedim vatanını milletini seven, mert, delikanl, bayrak aşığı yiğit gençler var. Onları çağırırız ülkeyi temsil ederiz çekme mekme yok dedim. Bilmiyorum yanlış mı demişim!

$\checkmark$-Vay kardeşim benim be gülüm. Nereden çıktın sen! Ahmet'im benim, ciğerim (Sevgi).

$\checkmark$-Hissedebiliyor musun ha! Hissedebiliyor musun seni ne kadar çok sevdiğimi (Sevgi).

$\checkmark$-Ben her gece geliyorum seni dinlemeye. Her gece geliyorum ama ha.

-Niye?

-Hayranız abi, seviyoruz. (Sevgi).

$\checkmark$-Müslüm, senin sesin boyundan da saçından da büyük. Bir makasla kesilmez. Senin sesin ancak sen susarsan kesilir. Anladın mı? (Dayanışma).

$\checkmark$-Paralanmış gitmiş oğlum kadının elleri üç kuruş kazanacağım diye. Görmüyor musun oğlum annenin halini! (Duyarlılık).

\section{$\checkmark$-Müsaaden var mı usta?}

-Dayı sen kendi ayağınla geldin kendi ayağınla gidiyorsun. Gitmek istiyorsun. Sen bilirsin deyince kavga çıkmazmıs.

-Hakkını helal et usta, helal et (ustasının elini öpüp başına koyuyor) (Saygı).

X Kendisini okula yazdıran abisine okuldan atıldığını söyleyen Ahmet'in bu sırada kolunu cam kırıkları ile kesmesi (Sorumluluk). 
X Doktorun Müslüm'e alkolün kendisine ciddi zarar verebileceğini, bir an önce alkolü bırakmas1 gerektiğini söylemesi ve tedavi için gerekli ilaçların yazılı olduğu reçeteyi vermesine rağmen Müslüm'ün bu reçeteyi atması ve alkol almaya devam etmesi (Sorumluluk).

X Alkollü olan Müslüm'ün sahnede şarkı söylemekte olan Muhterem Nur'a “o şarkıyı ben söyleyecektim" diyerek tokat atması (Sayg1).

Tablo 3: Araştırma Kapsamında İncelenen Filmlerde Yer Alan Değerlerin Frekans ve Yüzdelerine İlişkin

Veriler

\begin{tabular}{clcccccc}
\hline \multirow{2}{*}{ Sira Değer } & & \multicolumn{2}{c}{ Olumlu } & \multicolumn{2}{c}{ Olumsuz } & \multicolumn{2}{c}{ Toplam } \\
\cline { 2 - 8 } & & $\boldsymbol{f}$ & $\mathbf{9}$ & $\boldsymbol{f}$ & $\mathbf{\%}$ & $\boldsymbol{f}$ & $\mathbf{\%}$ \\
\hline 1 & Sayg1 & 14 & 7,22 & $\mathbf{8 0}$ & 38,46 & 94 & 23,38 \\
2 & Sorumluluk & $\mathbf{3 3}$ & 17,01 & 23 & 11,06 & 56 & 13,93 \\
3 & Duyarlılık & $\mathbf{2 2}$ & 11,34 & 20 & 9,62 & 42 & 10,45 \\
4 & Sevgi & $\mathbf{3 8}$ & 19,59 & 3 & 1,44 & 41 & 10,20 \\
5 & Dürüstlük & 9 & 4,64 & $\mathbf{2 9}$ & 13,94 & 38 & 9,45 \\
6 & Dayanışma & $\mathbf{2 4}$ & 12,37 & 8 & 3,85 & 32 & 7,96 \\
7 & Vatanseverlik & $\mathbf{2 1}$ & 10,82 & 0 & 0,00 & 21 & 5,22 \\
8 & Yardımseverlik & $\mathbf{1 6}$ & 8,25 & 4 & 1,92 & 20 & 4,98 \\
9 & ABÖV & 2 & 1,03 & $\mathbf{1 1}$ & 5,29 & 13 & 3,23 \\
10 & Barış & 2 & 1,03 & $\mathbf{1 0}$ & 4,81 & 12 & 2,99 \\
11 & Adalet & 2 & 1,03 & $\mathbf{9}$ & 4,33 & 11 & 2,74 \\
12 & Tasarruf & 3 & 1,55 & $\mathbf{4}$ & 1,92 & 7 & 1,74 \\
13 & Çalışkanlık & $\mathbf{6}$ & 3,09 & 0 & 0,00 & 6 & 1,49 \\
14 & Özgürlük & 0 & 0,00 & $\mathbf{4}$ & 1,92 & 4 & 1,00 \\
15 & Eşitlik & 0 & 0,00 & $\mathbf{3}$ & 1,44 & 3 & 0,75 \\
16 & Estetik & $\mathbf{1}$ & 0,52 & 0 & 0,00 & 1 & 0,25 \\
17 & Bilimsellik & $\mathbf{1}$ & 0,52 & 0 & 0,00 & 1 & 0,25 \\
\hline & $\quad$ Toplam & $\mathbf{1 9 4}$ & $\mathbf{1 0 0}$ & $\mathbf{2 0 8}$ & $\mathbf{1 0 0}$ & $\mathbf{4 0 2}$ & $\mathbf{1 0 0}$ \\
\hline
\end{tabular}

Tablo 3 incelendiğinde incelen dört filmde sosyal bilgiler ders programında belirtilen on sekiz değerden on yedi değerin yer aldığı bağımsızlık değerinin ise yer almadığı görülmektedir. İncelenen filmlerde bu değerler, doğrudan veya dolaylı olarak, 194'ü olumlu 208'i olumsuz olmak üzere toplamda 402 yerde geçmektedir.

İncelenen filmler genel olarak değerlendirildiğinde olumlu olarak en fazla yer alan değerlerin sırasıyla; sevgi: 38 (\%19,59), sorumluluk: $33(\% 17,01)$ ve dayanışma: $24(\% 12,37)$ değerleri olduğu, en az yer alan değerlerin ise estetik: $1(\% 0,52)$ ve bilimsellik: $1(\% 0,52)$ değerleri olduğu, bağımsızlık, eşitlik ve özgürlük değerlerinin ise incelenen dört filmin hiçbirisinde olumlu olarak yer almadığ1 bulgulanmıştır. 
Filmlerde olumsuz olarak en fazla yer alan değerlerin sırasıyla; sayg1: $80(\% 38,46)$, dürüstlük: 29 $(\% 13,94)$ ve sorumluluk: $23(\% 11,06)$ değerleri olduğu; en az yer alan değerlerin ise sevgi: $3(\% 1,44)$ ve eşitlik: $3(\% 1,44)$ değerleri olduğu, bilimsellik, bağımsızlık, çalışkanlık, estetik ve vatanseverlik değerlerinin ise incelenen dört filmin hiçbirisinde olumsuz olarak yer almadığı sonucuna ulaşılmıştır.

\section{Tartışma, Sonuçlar ve Öneriler}

Araştırma verilerinden elde edilen bulgular 1şığında ortaya çıkan sonuçlar şu şekildedir: Dügün Dernek 2: Sünnet filminde on iki farklı değere yönelik toplamda 97 ögenin yer aldığı, film içerisinde olumlu olarak en fazla geçen değerlerin sevgi, yardımseverlik, dürüstlük ve sorumluluk olduğu, film içeresinde olumsuz olarak en fazla yer alan değerlerin ise dürüstlük saygı ve duyarlılık değerleri olduğu anlaşılmıştır. Filmde yer alan değerler genel olarak değerlendirildiğinde içerdiği olumsuz değer ögelerinin, olumlu değer ögelerinden fazla olduğu görülmektedir. Ayrıca Düğün Dernek 2: Sünnet filmi incelenen filmler arasında en az olumlu değer ögesine sahip filmdir. Dağ 2 filminde on iki farklı değere yönelik toplamda 69 ögenin yer aldığı, film içerisinde olumlu olarak en fazla geçen değerlerin sorumluluk, sevgi ve vatanseverlik olduğu, film içeresinde olumsuz olarak en fazla yer alan değerlerin ise $\mathrm{ABÖV}$, duyarlılık ve dürüstlük olduğu anlaşılmıştır. Filmde yer alan değerler genel olarak değerlendirildiğinde içerdiği olumlu değer ögelerinin, olumsuz değer ögelerinden fazla olduğu görülmektedir. Dağ 2 filmi incelenen filmler arasında en az olumsuz değer ögesine sahip filmdir. Recep İvedik 5 filminde on dört farklı değere yönelik toplamda 150 değer ögesinin yer aldığı, film içerisinde olumlu olarak en fazla geçen değerlerin sorumluluk, vatanseverlik ve dayanışma olduğu, filmde en fazla geçen olumsuz değerlerin ise saygı, sorumluluk, dayanışma ve dürüstlük değerleri olduğu anlaşılmıştır. Film genel olarak değerlendirildiğinde içerdiği olumsuz değer ögelerinin, olumlu değer ögelerinden çok daha fazla olduğu ortaya çıkmıştır. Recep İvedik 5 filmi incelenen filmler arasında en fazla olumsuz değer ögesine sahip filmdir. Müslüm filminde on iki farklı değere yönelik toplamda 86 değer ögesinin yer aldığı, film içerisinde en fazla geçen değerlerin sevgi, dayanışma ve sorumluluk olduğu, filmde en fazla geçen olumsuz değerlerin ise sorumluluk ve saygı değerleri olduğu anlaşılmıştır. Film genel olarak değerlendirildiğinde içerdiği olumlu değer ögelerinin, olumsuz değer ögelerinden, fazla olduğu ortaya çıkmıştır. Bununla birlikte Müslüm filmi incelenen filmler arasında en fazla olumlu değer ögesine sahip filmdir.

İncelenen dört film genel olarak değerlendirildiğinde on yedi farklı değerin doğrudan veya dolaylı olarak, 194'ü olumlu 208'i olumsuz olmak üzere toplamda 402 yerde geçtiği sonucuna ulaş1lmıştır. Filmlerin genelinde olumlu olarak en fazla yer alan değerlerin sırasıyla; sevgi, sorumluluk ve dayanışma değerleri olduğu; olumsuz olarak en fazla yer alan değerlerin ise sırasıyla; saygı, dürüstlük ve sorumluluk değerleri olduğu sonucuna ulaşılmıştır. İncelenen dört filmin hiçbirisinde bilimsellik, çalışkanlık ve vatanseverlik değerlerine yönelik olumsuz ögeler buna karşılık dört filmin hiçbirisinde özgürlük ve eşitlik değerlerine yönelik olumlu ögeler yer almamaktadır. Bağımsızlık değeri ise incelenen filmlerde olumlu veya olumsuz olarak yer almamaktadır. İncelenen filmlerin tamamında bilimsellik, çalışkanlık, dayanışma, duyarlılık, estetik, sevgi, sorumluluk, vatanseverlik ve yardımseverlik değerlerine yönelik olumlu ögeler olumsuz ögelerden daha fazlayken ABÖV, adalet, barış, dürüstlük, eşitlik, özgürlük, tasarruf ve saygı değerlerine yönelik olumsuz ögeler olumlu ögelerden daha fazladır.

Dağ 2 ve Müslüm filmlerinde olumlu değer ögeleri olumsuz değer ögelerinden daha fazla olmakla birlikte Dügün Dernek 2: Sünnet ve Recep İvedik 5 filmlerinde olumsuz değer ögeleri olumlu değer ögelerinden daha fazladır. Bunlara ek olarak filmler içerisinde yer alan olumlu ve olumsuz değer ögeleri 
oransal olarak karşılaştırıldığında Dağ 2 filminin içerdiği olumlu değerler (içerdiği değer ögelerinin \%80'i olumlu) diğer üç filmden daha fazladır. Recep İvedik 5 filminin içerdiği olumsuz değerler ise (içerdiği değer ögelerinin \%69’u olumsuz) diğer üç filmden daha fazladır.

Belirtilmesi gereken diğer bir nokta ise özellikle Dağ 2 ve Müslüm filmlerinde zaman zaman olumsuz değer ögelerinin, kahramanların pişmanlık duyması ya da hatalarının farkına varması suretiyle olumlu bir duruma evirilmesidir. Zaten bu iki filmde de olumlu ögelerin olumsuz ögelerden fazla olduğu ve kahramanlarının da kendilerine özenilecek niteliklere sahip oldukları söylenebilir.

Ancak komedi türünde yapılan filmlerde filmlerin kahramanları genellikle değerlerle bağdaşmayacak olumsuz davranışları veya sözlerinden dolayı pişmanlık duymamakta ve hatalarını kabul etmemektedir. Daha da önemlisi kahramanların karakter özellikleri de bu hal ve hareketler üzerine inşa edilmekte ve bu karakterler seyirciye kendisine özenilmesi gereken tipler olarak sunulmaktadır. İncelenen komedi türündeki filmlerde (Düğün Dernek 2: Sünnet ve Recep İvedik 5) güldürü unsurlar1 genellikle değerlerle bağdaşmayacak şekilde sunulmaktadır ve zaten bu filmlerde yer alan olumsuz değer ögeleri olumlu ögelerden çok daha fazladır.

Değerleri olumsuz etkileyen söz ve davranışların filmlerin "kötü karakterleri" tarafından sergilenmesi durumu ise ayrı bir değerlendirmeye muhtaçtır. Olumsuz olan bu söz ve davranışları filmlerin kötü karakterleri sergilediği için izleyiciler üzerinde olumsuz bir etki bırakmaması muhtemeldir.

Filmlerin konuları da içerdikleri değer ögeleri ile yakından ilgilidir. Örneğin araştırma kapsamında incelenen filmlerden iki tanesinde (Dağ 2 ve Recep İvedik 5) vatanseverlik değeri diğer iki filmden çok daha fazla aktarılmıştır. Dağ 2 filmi bir terör örgütü tarafindan kaçırılan Türk vatandaşı bir gazetecinin özel kuvvetler tarafından kurtarılmasını konu almakta, Recep İvedik 5 ise Avrasya Gençlik Oyunları'nda Türkiye'yi temsilen Makedonya'ya giden Türk milli takım kafilesinin serüveni aktarılmaktadır. Dolayısıyla bu filmlerde vatanseverlik değerine yönelik iletilerin fazla olmasında konusunun payı oldukça fazladır.

Görüldüğü gibi incelenen filmlerde olumlu değer ögelerine rastlandığı gibi olumsuz değer ögeleri de yer almaktadır. Buradan hareketle her filmin değerlerin aktarılması sürecinde bir araç olarak kullanılmaması gerektiği söylenebilir. Özellikle bu amaç için kullanılacak filmlerin içerikleri mutlaka kontrol edilmelidir.

Alanyazında çizgi filmlerin ve filmlerin değerler ve değerler eğitimi bağlamında incelenmesi amaciyla hazırlanan çalışmalar mevcuttur. Sevim (2013) çocuklara yönelik programlar içerisinde çizgi filmlerin değerler eğitimi bakımından karşılaştırılması amacıyla hazırladığı çalışmasında yardımseverlik ve iş birliği değerlerinin diğer değerlere göre daha fazla yer aldığ 1 sonucuna ulaşmıştır. $\mathrm{Bu}$ çalışmada da yardımseverlik değerine ilişkin olumlu ögelerin olumsuz ögelerden çok daha fazla olduğu sonucuna ulaşmakla birlikte yardımseverlik değerinin incelenen filmlerin genelinde en fala yer alan altıncı değer olduğu bulgulanmıştır. Yorulmaz (2013a) Caillou çizgi filmini din ve değerler eğitimi bağlamında incelediği çalışmasında çizgi filmin ana karakteri olan Caillou'nun çoğunlukla olumlu karakter özelliklerine sahip olduğu, çizgi filmin ise değerleri geliştirici ögeler barındırdığı sonucuna ulaşmıştır. Yine Yorulmaz (2013b) tarafından hazırlanan çalışmada Pepee çizgi filmi din ve değerler eğitimi bağlamında incelenmiştir. Çalışma sonuçlarına göre çizgi filmin ana karakteri olan Pepee'nin olumsuz karakter özelliklerine sahip olduğu ve model olduğu izleyicilere olumsuz örnek teşkil ettiği sonucuna ulaşılmıştır. Bu çalı̧̧mada incelenen dört filmden ikisinin (Dağ 2 ve Müslüm) ana karakterlerinin olumlu karakter özelliklerine sahip olduğu söylenebilirken, diğer iki filmin (Dügün dernek 2: Sünnet ve Recep İvedik 5) ana karakterleri genellikle olumsuz karakter özellikleriyle ön plana 
çıkmaktadır. Ayrıca incelenen filmlerin ikisinde olumlu değer ögeleri fazla iken ikisinde olumsuz değer ögeleri daha fazladır. Karakuş (2015), Niloya çizgi filminde yer alan değerleri incelediği çalışmasında duyarlılık, hoşgörü, sevgi ve iyilik değerlerinin Niloya çizgi filminin incelenen her bölümünde yer aldığı sonucuna ulaşmıştır. Bu çalışmada da duyarlılık ve sevgi değerleri incelenen filmlerin tamamında yer almaktadır. Hoşgörü ve iyilik değerleri ise sosyal bilgiler öğretim programında belirtilen değerler arasında yer alamadığı için incelemeye tabi tutulmamıştır. İnan (2016) TRT Çocuk kanalında 2016 yılında yayınlanan on bir farklı çizgi filmi evrensel ve yerel değerler bağlamında incelemiştir. Çalışmada izlenilen 11 farklı çizgi film bir bütün olarak değerlendirildiğinde yardımlaşma, işini en iyi şekilde yapma, çalışkanlık, dayanışma ve sevgi değerlerinin çokça vurgulandığı sonucuna ulaşılmıştır. Bu çalışma kapsamında incelenen filmlerde dayanışma, sevgi ve yardımseverlik değerlerinin olumlu olarak çokça yer aldığ (2019), TRT Çocuk kanalında yayınlanan Rafadan Tayfa çizgi filmini içerdiği değerler bağlamında incelemiştir. Araştırmada Rafadan Tayfa çizgi filminin değerler eğitimi açısından genellikle olumlu bir içeriğe sahip olduğu, olumsuz değer ögelerine çok az yer verildiği sonucuna ulaşılmış en fazla yer alan değerlerin de yardımseverlik, selamlaşma, çalışkanlık ve saygı değerleri olduğu vurgulanmıştır. Demir (2019), çalışmasında iki yerli ve iki yabancı çizgi filmi incelemiş, yerli çizgi filmlerin yabancı çizgi filmlere göre dini ve kültürel değerlere daha fazla yer verdiği sonucuna ulaşmış ayrıca yabancı çizgi filmlerin yerli çizgi filmlerden çok daha fazla olumsuz değer unsuru barındırdığını belirtmiştir. Ünsal (2019) öğrenci velilerine uyguladığ1 anket sonucunda çocukların en fazla izlediği beş çizgi filmi belirlemiş ve bu çizgi filmlerin beşer bölümünü içerdiği değerler bağlamında incelemiştir. Araştırma sonucunda incelenen çizgi filmlerde en fazla yer alan değerlerin sırasıyla saygı, sevgi, yardımlaşma ve sorumluluk değerleri olduğu sonucuna ulaşılmıştır. Bu çalışmada da saygı, sevgi, yardımlaşma ve sorumluluk değerlerine incelenen filmlerde sıklıkla yer verildiği bulgulanmıştır.

Beldağ ve Yarar Kaptan (2017), Arabalar filmini içerdiği değerler açısından incelemişlerdir. Araştırmacılar çalışmalarında saygı, alçakgönüllülük, duyarlılık, iş birliği, dürüstlük, sevgi ve yardımseverlik değerlerinin film içerisinde daha çok vurgulandığı sonucuna ulaşmışlardır. Benzer olarak bu çalışmada da saygı, duyarlılık, dürüstlük ve sevgi değerleri incelenen filmlerde fazlaca yer almaktadır. Kavun (2018), 82 adet Kemal Sunal filmini içerdiği değerler bağlamında analiz etmiştir. Araştırma sonucunda incelenen filmlerde 29 farklı değerin yer aldığ 1 , filmlerde en fazla yer alan değerlerin ise sevgi, sayg1 ve aile birliğine önem verme olduğu sonucuna ulaşılmıştır. Bu çalışmada da sayg1 ve sevgi değerlerinin incelenen filmlerde sıklıkla yer aldığı bununla birlikte aile birliğine önem verme değerine ise daha az yer verildiği sonucuna ulaşılmıştır. Aynı çalışmada, incelenen filmlerde olumsuz unsurların (argo ifadeler, küfürler, olumsuz söz ve davranışlar vb.) sıklıkla yer aldığı bu bulgunun da bu çalışmanın bulguları ile benzerlik taşıdığı söylenebilir. Turhan (2018) Türk yapımı altı adet animasyon filmini içerdiği değerler bağlamında incelemiştir. Çalışma sonucunda incelenen filmlerde toplam 156 değer ögesinin yer aldığı tespit edilmiştir. Filmlerde en fazla yer alan değerlerin ise sevgi değeri olduğu sonucuna ulaşılmıştır. Çalışmada incelenen filmlerde olumlu ve olumsuz değer ögelerinin yer aldığı vurgulanmakla birlikte animasyon filmlerinin değerler eğitiminde kullanılabileceği belirtilmiştir. Aydemir (2019), Zeki Alasya-Metin Akpınar filmlerini değerler eğitimi bağlamında incelemiştir. Çalışmada incelenen filmlerde en fazla yer alan değerin sevgi değeri ve olumsuz anlamda en fazla yer alan olumsuz değerin de dürüstlük değeri olduğu sonucu bu çalışmanın sonuçları ile benzerlik göstermektedir. Kanar (2019), animasyon filmlerinin öğrencilerin değer gelişimine etkilerini belirlemek amacıyla hazırladığ çalışma sonucunda animasyon filmlerin çocuklarda değer kazanımında etkili oldukları, empati becerilerini olumlu yönde etkiledikleri ve aktarılan değerlerin çocuklarda iz bıraktığı sonucuna ulaşmıştır. 
Dizi ve filmlerin içerdiği değerler bağlamında incelenmesine yönelik çalışmaların yanında dizi ve filmlerin farklı konular üzerindeki etkilerini incelemeye yönelik çeşitli çalışmalar da mevcuttur. Kim, Agrusa, Lee ve Chon (2007) Winter Sonata isimli Kore dizisinin Japon turistlerin Kore'yi ziyaret etmeleri üzerindeki etkisini incelemişler ve bu dizinin Japon turistlerin Kore'yi ziyaret etmeleri üzerinde olumlu bir etkiye sahip olduğu sonucuna ulaşmışlardır. Semerci ve Kalçık (2017) lise öğrencileri ile yaptıkları çalışmada TV dizilerinin öğrencilerin yaşam boyu öğrenmeleri üzerinde etkili olduğu, öğrencilerin dizilerde geçen konuşmaları günlük yaşamda kullandıkları, meslekleri tanıma ve seçmede olumlu olarak etkilendikleri, dizi karakterlerini kendilerine örnek aldıkları, onlar gibi davranmaktan hoşlandıkları bununla birlikte dizilerde gösterilen bazı olay ve kişilerden olumsuz olarak etkilendikleri sonucuna ulaşmışlardır. Güngör ve Uysal (2019), Nevşehir'de çekilen film ve dizilerin, Nevşehir'e gelen yerli turistlerin tercih süreci üzerindeki etkisini belirlemek amacıyla hazırladıkları çalışmada bu film ve dizilerin yerli turistlerin Nevşehir'i tatil yeri olarak tercih etmeleri üzerinde motive edici bir etkiye sahip olduğu sonucuna ulaşmışlardır. Özturhan (2019), İmam Hatip liselerinde okuyan kız öğrencilerin Kore dizilerinden etkilendikleri, bu dizilere ve dizilerin kahramanlarına hayranlık duydukları sonucuna ulaşmış ayrıca bu dizilerin misyonerlik faaliyetlerine katkıda bulunduğu ve değerlerimizle bağdaşmayan unsurlarının Türk milli ve manevi değerleri üzerinde olumsuz bir etkiye sahip olduğu yorumunda bulunmuştur.

\section{Öneriler}

- Bu araştırmada 2015-2018 yılları arasında vizyona giren dört tane film incelenmiştir. Daha fazla sayıda film değerler eğitimi bağlamında incelenebilir.

- Günümüzde yayınlanan televizyon dizileri de benzer bir incelemeye tabi tutulabilir ve film ve diziler değerler bağlamında karşılaştırılabilir.

- Geçmiş dönemlerde vizyona giren Türk filmlerinin de içerdiği değerler bağlamında incelenmesi yardımıyla geçmiş ve günümüz filmlerinin içerdiği değerler bağlamında karşılaştırılması yapılabilir. Bu sayede geçmişten günümüze filmlerde aktarılan değerlerde meydana gelen değişim ortaya koyulabilir.

- Filmlerde yer alan olumlu ama özellikle de olumsuz değer unsurlarının izleyici üzerinde nasıl bir etkiye sahip olduğu konusunda çalışmalar yapılabilir.

- İzleyicilerin ve özellikle de çocukların filmlerde yer alan olumsuz unsurlardan etkilenmemesi amacıyla ilgili kurumların önlem almaları, ailelerin bu konuda bilinçlendirilmeleri, ailelerin çocuklarına izletecekleri filmlerin içeriğine hâkim olmaları, gerekirse öncelikle filmleri kendilerinin izlemeleri ve olumsuz örnek olabilecek filmlerden çocuklarını uzak tutmaları sağl1klı toplum yapısı ve değerlerine sahip bireylerin varlığı açısından önem arz etmektedir. 


\section{Kaynaklar}

Akıncı Yüksel, N. A. (2015). Kültürel bir ürün olarak Türkiye'de sinema filmlerinde okul, öğretmen ve öğrenci temsilleri. Global Media Journal: Turkish Edition, 6(11), 1-17.

Aydemir, S. (2019). Değerler eğitimi bağlamında Zeki Alasya-Metin Akpınar filmleri (Yayımlanmamış yüksek lisans tezi). Ondokuz Mayıs Üniversitesi Eğitim Bilimleri Enstitüsü, Samsun.

Beldağ, A. ve Yarar Kaptan, S. (2017). Arabalar filminin içerdiği değerlere ilişkin bir inceleme. Kırşehir Ĕğitim Fakültesi Dergisi. 18(2), 487-499.

Birkök, M. C. (2008). Bir toplumsallaştırma aracı olarak eğitimde alternatif medya kullanımı: Sinema filmleri. Uluslararası İnsan Bilimleri Dergisi, 5(2), 1-12.

Bogdan, R. C. and Biklen, S. K. (1992). Qualitative research for education to theory and methods. Boston: Allyn and Bacon A Division of Simon \& Schuster Inc.

Box Office Türkiye (2019). Erişim adresi: https://boxofficeturkiye.com/

Creswell, J. W. (2003). Research design. Qualitative, quantitative, and mixed methods approaches. Second Edition. Sage publications Inc.

Demir, R. (2019). Türkiye'de çocuk kanallarında yayınlanan çizgi filmlerde dini ve kültürel değerler eğitimi (Yayımlanmamış doktora tezi). Sakarya Üniversitesi Sosyal Bilimler Enstitüsü, Sakarya.

Eşitti, Ş. (2016). Çizgi filmlerde küresel ve yerel kültürün inşası: Caillou ve Pepee örneği. Karadeniz Uluslararası Bilimsel Dergi, 32(32), 125-144. doi: 10.17498/kdeniz.279674

Güngör, Ş. and Uysal, A. (2019). Film tourism: The influence of film and tv series on the tourism activities in Nevşehir. International Journal of Geography and Geography Education, 39, 189-202. doi: 10.32003/iggei.489920

Halstead, J. M. and Taylor, M. J. (2000). Learning and teaching about values: a review of recent research. Cambridge Journal of Education. 30(2), 169-202.

İnan, T. (2016). Çocuk medyasında evrensel ve yerel değerlerin aktarımı: TRT Çocuk kanalı örneği. Akademik Sosyal Araştırmalar Dergisi, 4(25), 200-212.

Kanar, S. (2019). Animasyon filmlerinin öğrencilerin değer gelişsimine etkileri: Arabalar 1 animasyon filmi örneği (Yayımlanmamış yüksek lisans tezi). Marmara Üniversitesi Eğitim Bilimleri Enstitüsü, İstanbul.

Karaca, S. S. (2019). Çizgi filmlerde değerler eğitimi, değerler eğitimi açısından Rafadan Tayfa çizgi filminin incelenmesi. (Yayımlanmamış yüksek lisans tezi). İzmir Kâtip Çelebi Üniversitesi Sosyal Bilimler Enstitüsü, İzmir.

Karakuş, N. (2015). Okul öncesi döneme hitap eden tema içerikli çizgi filmlerin değerler eğitimine katkısı yönünden değerlendirilmesi (Niloya Örneği). Değerler Eğitimi Dergisi, 12(3), 251-277.

Kavun, M. (2018). Çocuklara değer aktarımında Türk sinemasının rolü: Kemal Sunal filmleri örneği (Yayımlanmamış yüksek lisans tezi). Ondokuz Mayıs Üniversitesi Eğitim Bilimleri Enstitüsü, Samsun.

Keleş, E. ve Çepni, S. (2006). Beyin ve öğrenme. Journal of Turkish Science Education, 3(2), 66-82.

Kızılçelik, A. ve Erjem, Y. (1994). Açıklamall sosyoloji terimler sözlüğü. Atilla Kitabevi, Ankara.

Kim, S.S., Agrusa, J., Lee, H. and Chon, K. (2007). Effects of Korean television dramas on the flow of Japanese tourists. Tourism Management, 28, 1340-1353.

Öncü, A. (2015). Değerler eğitimi bağlamında Ahmet Hamdi Tanpınar ve Oğuz Atay'da değerler (Yayımlanmamış doktora tezi). Üniversitesi Sosyal Bilimler Enstitüsü, İstanbul.

Özturhan, F. (2019). İmam Hatip Lisesi öğrencilerinin Güney Kore dizileri izleme durumlart ve dizilerin etkileri (Yayımlanmamış yüksek lisans tezi). Necmettin Erbakan Üniversitesi Sosyal Bilimler Enstitüsü, Konya.

Öztürk, B. (1999). Öğrenme ve öğretmede dikkat. Milli Eğitim Dergisi, 144, 51-58.

Radyo ve Televizyon Üst Kurulu (RTÜK) (2018). Televizyon İzleme Eğilimleri Araştırması-2018. Erişim adresi: https://www.rtuk.gov.tr/assets/Icerik/AltSiteler/televizyonizlemeegilimleriarastirmasi2018.pdf. 
Radyo ve Televizyon Üst Kurulu (RTÜK) (2020). Çocukların medya kullanım alışkanlıkları ve siber zorbalık araştırması. Erişim adresi: https:/www.rtuk.gov.tr/haberler/3787/8175/dikkat-ceken-arastirmaninsonuclari-aciklandi.html.

Roberts, L. C., Dean, E. and Nienhuis, T. (2003). Lights, camera, action: Teaching with feature film in the social sciences. Mountain Rise, 1(1).

Russell III, W. B. and Waters, S. (2013). "Reel” character education: Using film to promote global citizenship. Childhood Education, 89(5), 303-309.

Semerci, N ve Kalçık, C. (2017). Televizyonda yayınlanan dizilerin lise öğrencilerinin yaşam boyu öğrenmesine etkisi öğrenci görüşleri: Bir olgu bilim çalışması (Bartın ili örneği). Bartın Üniversitesi Ĕ̆itim Fakültesi Dergisi, 6(1), 237-262. doi: 10.14686/buefad.280034

Sevim, Z. (2013). Çizgi filmlerin değerler eğitimi bakımından karşılaştırılması (Yayımlanmamış yüksek lisans tezi). Uşak Üniversitesi Sosyal Bilimler Enstitüsü, Uşak.

Şahin, N. (2017). Cengiz Aytmatov'un eserlerinin değerler eğitimi bağlamında incelenmesi ve ortaokul Türkçe ders kitapları için metin önerileri (Yayımlanmamış doktora tezi). Atatürk Üniversitesi Eğitim Bilimleri Enstitüsü, Erzurum.

Torun, F. (2019). Hüseyin Nihâl Atsız'ın edebî eserlerinin değerler eğitimi açısından incelenmesi (Yayımlanmamış doktora tezi). Atatürk Üniversitesi Eğitim Bilimleri Enstitüsü, Erzurum.

Turhan, H. B. (2018). Türk yapımı animasyon filmlerinde değer aktarımı üzerine inceleme (Yayımlanmamış yüksek lisans tezi). Siirt Üniversitesi Sosyal Bilimler Enstitüsü, Siirt.

Türk Dil Kurumu (TDK), (2019). Türk Dil Kurumu Sözlükler. Erişim adresi: https://sozluk.gov.tr/.

Ulusoy, K. ve Dilmaç, B. (2016). Değerler ĕgitimi (4. Baskı). Ankara: Pegem Akademi.

Ulusoy, K. (2019). Karakter dĕgerler ve ahlak ĕgitimi. Ankara: Pegem Akademi.

Ünsal, S. (2019). Okul öncesi döneme yönelik çizgi filmlerin değerler bağlamında incelenmesi (Yayımlanmamış yüksek lisans tezi). Karabük Üniversitesi Sağlık Bilimleri Enstitüsü, Karabük.

Yeşil, R.ve Aydın, D. (2007). Demokratik değerlerin eğitiminde yöntem ve zamanlama. Türkiye Sosyal Araştırmalar Dergisi, 11(2), 65-84.

Yıldırım, A. ve Şimşek, H. (2011). Sosyal bilimlerde nitel araştırma yöntemleri. Ankara: Seçkin Yayıncılık.

Yorulmaz, B. (2013a). Din ve değerler eğitimi açısından Caillou çizgi filminin değerlendirilmesi. Diyanet İlmî Dergi, 49(3). 127-143.

Yorulmaz, B. (2013b). Pepee çizgi filminin din ve değerler eğitimi açısından değerlendirilmesi. Uluslararası Sosyal Araştırmalar Dergisi, 6(24). 438-448.

Weinstein, P. (2001). Movies as the gateway to history: The history and film project, The History Teacher, 35(1), 27-48. 


\section{Extended Abstract}

Values are behaviors that are defined and accepted as correct and beautiful by the general public. People are not born as having values. However, they can gain these values through their lives, experiences, environment and education (Yeşil and Aydın, 2007). All efforts made for the transfer of values can be defined as values education. Today, various methods and tools are used to transfer values. One of these tools are movies that can easily reach large audiences With the help of movies, a message can be easily transferred to the viewer. In addition, the heroes in the movies can become role models for young people and children. Today, people have the opportunity to easily access movies in various environments such as television, internet and movie theaters. In addition, the interest of Turkish people who watch TV for a significant part of the day and prefer Turkish movies rather than foreign movies in movie theaters is remarkable.

Considering the data regularly published by RTÜK every year, Turkish people watch an average of 3 hours and 34 minutes of television daily in 2018 (RTÜK, 2018). According to another study prepared by RTÜK, the most frequently watched program type by secondary school students was series with $51.5 \%$, movies with $41 \%$ and live sports competitions / sports programs with $28 \%$ (RTÜK, 2020). The interest of the Turkish people in the movies also has been increasing over the years. In Turkey 27 million 800 thousand people in 2005 watched the movies in movie theaters. In 2018, this number reached 70 million 400 thousand people. Considering all these data, it becomes important to examine the movies in terms of content. This study has been prepared in order to determine the values in the Turkish movies that were released between 2015-2018.

The research has been prepared in accordance with the qualitative research method. Document analysis method was used to collect data. The data sources of the research are four Turkish movies (Düğün Dernek 2: Sünnet; Dağ 2; Recep İvedik 5 and Müslüm), which were released between 20152018. Criterion sampling method, which is one of the purposeful sampling methods, was used in sample selection. As criterion, the viewing rates of the movies were taken into consideration. The most watched Turkish movie of each year in 2015-2018 was included in the research. Research data were analyzed with descriptive analysis method. The movies examined within the scope of the research were watched twice, taking into account the content observation form created by the researcher. Verbal and visual (non-verbal items) value expressions in the movies were recorded on the content observation form.

When the four movies analyzed are evaluated in general, it is concluded that seventeen different values pass directly or indirectly in a total of 402 places, 194 positive and 208 negative. The value items in the four movies examined are as follows: Dügün Dernek 2: Sünnet: 97 value items (34 positive and 63 negative); Dağ 2: 69 value items (55 positive and 14 negative); Recep İvedik 5; 150 value items (47 positive and 103 negative); Müslüm: 86 value items (58 positive and 28 negative). In two of the four movies (Dağ: 2 and Müslüm) examined within the scope of the research, the positive value items are more than the negative value items. However, in the other two of the four movies examined (Dügün Dernek 2: Sünnet and Recep İvedik 5), negative value items are more than the positive value items. It was understood that the values of love, responsibility and solidarity were the most common positive values in the movies examined. On the other hand, it is concluded that the values of respect, honesty and responsibility are the most common negative values in the movies examined.

The results obtained in the research were compared with similar studies in the literature and suggestions were made based on the results. 